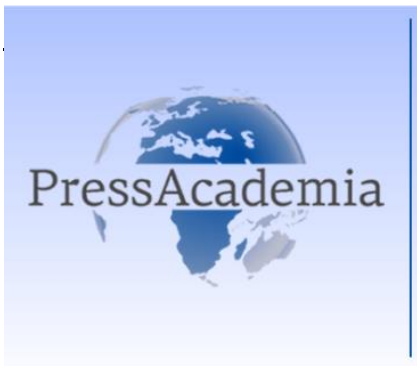

Press Academia Procedia

Global Business Research Congress (GBRC), May 24-25, 2017, Istanbul, Turkey

\title{
THE NEXUX BETWEEN FINANCIAL DEVELOPMENT, FOREIGN DEPOSITS, RETAIL BANKING AND FINANCIAL INCLUSION: THE JORDANIAN CASE
}

\author{
DOI: 10.17261/Pressacademia.2017.398 \\ PAP-GBRC-V.3-2017(13)-p.118-130
}

Ghassan Omet ${ }^{1}$, Morad Abdel-Halim ${ }^{2}$

${ }^{1}$ Faculty of Business, Department of Finance, University of Jordan, Jordan.gomet@ju.edu.jo

${ }^{2}$ General Budget Department, Ministry of Finance \& Business Economics, University of Jordan. Abdalhalim.morad@gmail.com

\section{To cite this document}

Omet, G., M.A. Halim, (2017). The nexus between financial development, foreign deposits, retail banking and financial inclusion: the Jordanian case. PressAcademia Procedia (PAP), V.3, p.118-130

Permanent link to this document: http://doi.org/10.17261/Pressacademia.2017.398

Copyright: Published by PressAcademia and limited licenced re-use rights only.

\begin{abstract}
As a major part of the Jordanian financial system, this paper examines the banking sector at both the macro and micro levels. Based on the time period 1982-2015, and time series methodologies (co-integration, Vector Error Correction Model, and Granger Causality), the macrolevel analysis examines the impact of foreign exchange deposits on financial development. Using the Seemingly-Unrelated Regression (SUR), the micro-level aspect examines the impact of foreign exchange deposits and retail banking on the performance of banks in terms of their net interest margin and accounting performance. Finally, the fact that greater financial inclusion promotes credit to the private sector, we estimate an Ordered Probit Model to examine the determinants of financial inclusion in Jordan. We conclude that foreign exchange deposits reflect weak evidence in explaining the variability of bank credit. In other words, foreign exchange deposits do not promote financial development. The micro-level analysis, on the other hand, reveals that foreign exchange deposits and retail banking impact bank profitability in a positive manner. However, this impact (positive) comes only at the expense of widening net interest margins. Finally, the results reveal that higher income, better education, being a man, and being older are associated with greater levels of financial inclusion. Naturally, based on the empirical results, the paper outlines a number of recommendations whose aim is to promote financial development as well as the performance of the banking system.
\end{abstract}

Keywords: Financial Development, dollarization, net-interest margin, return on assets, financial inclusion.

JEL Classification: G20, G21, N25.

\section{INTRODUCTION}

The economic impact of financial development has long been a controversial issue. Indeed, even Nobel Laureates in economics could not agree. For example, while Bagehot (1873), and Schumpeter (1912) argued that financial development impacts economic growth in a positive manner, another Laureate (Robinson, 1952), states that real economic growth that affects financial development. To make the issue even more confusing, Lucas (1988), who is also a Nobel Laureate, argues that the impact of financial development on growth is exaggerated.

Irrespective of what the relationship between financial development and growth is, one can argue that banks (and stock markets) provide economies with a myriad of financial services which facilitate economic growth. These include the pooling of savings, allocation of capital resources, monitoring of investments, risk diversification and risk management, and the exchange of goods and services (Levine, 2004). 
Notwithstanding the fact that the role of financial development is still controversial, one can also argue that the burgeoning empirical literature, on average, shows that economies with more developed financial systems tend to witness stronger economic growth, have less poverty, and to suffer less from income inequality. This literature is reviewed in two recent papers by Dabla-Norris and Srivisal (2013) and Beck (2016).

Given the economic importance of financial development in general, and banks in particular, one should not be surprised to learn that these two elements (financial development and bank development) have captured the attention of numerous research papers. Within the context of this paper, this literature can be classified under three groups. These are outlined below.

The first group is concerned with measuring financial development. Whilst most of the literature approximates financial development by the ratio of private credit to Gross Domestic Product (GDP), it must be stated that this concept is multidimensional. For example, the International Monetary Fund (IMF) publishes an index of financial development that is based on measures of financial depth, access, and efficiency measures. Within this spirit, Svirydzenka (2016) developed nine indices that summarize how developed financial institutions and markets are in 183 countries. The World Bank is also involved in measuring financial development and this effort includes benchmarking financial systems (Cihak et al., 2012) and the extent of financial inclusion (proportion of adults with a bank account, and other measures) for an equally large set of countries.

The second group examines what really determines financial development. This line of research attempts to explain why some nations have more financially developed systems than others. For example, based on their analysis of financial development in the Middle East and North Africa (MENA) region, it is reported that openness to foreign trade promotes financial development. In other words, economic integration is key policy priority to improve financial development, and hence, economic growth (Cherif and Dreger, 2016).

Finally, the third group of research papers examines the performance of banks in terms of the determinants of their accounting performance and net interest margin. This research is due to the classical paper by Demirguc-Kunt and Huizinga (1999). Here, it is useful to note that the performance of banks in the MENA region is examined by Caporale et al. (2015). In addition, this group of research looks at a myriad of other issues including measuring bank competition and its impact on financial stability, (recently reviewed by Zigraiova and Havranek, 2015), impact of foreign banks' entry on the performance of local banks, (for example, Jordanian banks are examined in terms of this issue by Yaseen et al., 2015), and the impact of foreign exchange deposits on the performance of banks. A recent paper that discusses the issue of dollarization in terms of its measures, causes, consequences, and policy challenges is provided by Marcelin and Mathur (2016).

Relative to the above brief account of the financial development literature and its related empirical research issues, the objectives of this paper are three-fold.

(1) To examine the determinants of financial development in Jordan. Based on the time period 1982-2015, this paper examines the impact of foreign exchange deposits (and other factors) on bank credit to the private sector.

(2) To examine the impact of foreign exchange deposits and retail banking (and other factors) on the performance banks (2008-2015), in terms of their return on assets and net interest margin.

(3) To examine financial inclusion in Jordan and its determinants. Based on the World Bank Findex database for 2014, we analyze financial inclusion in Jordan.

The importance of this research paper, it is argued, is based on several observations. These are outlined below.

First, relative to the Jordanian economy, the banking system is large. Licensed banks' 2015 assets are equivalent to about 180 percent of GDP. Indeed, this proportion is larger than that in, for example, Poland (60 percent), Saudi Arabia (93 percent), Turkey (114 percent), and comparable to the 190 percent that prevail in Japan (World Bank database).

Second, listed Jordanian banks differ significantly in terms of their respective foreign exchange deposits to total deposits. During the period 2008-2015, the minimum and maximum values of deposits in foreign exchange to total deposits were equal to 0.1 percent and 88.6 percent respectively.

Third, listed Jordanian banks differ significantly in terms of their respective involvement in the retail banking sector. During the period 2008-2015, the minimum value and maximum values of bank credit to individuals as a proportion of total credit were equal to 1.08 percent and 54.28 percent respectively.

Fourth, based on the World Bank's estimates, the extent of financial in Jordan is relatively low. Indeed, the currently existing 24.6 percent of the adult population having a banking account is much lower than those which exist in, for example, Finland (100 percent), Bahrain (81.9 percent), Saudi Arabia (69.4 percent), and Turkey (56.7 percent). In actual fact, this low proportion is comparable to only those in Palestine (24.4 percent), and Tunisia (27.4 percent). 
Finally, and as one might expect, if foreign exchange deposits prove to be significant in their impact on financial development at the macro-level, some policy recommendations must be provided. In addition, if foreign exchange deposits and retail banking prove to impact bank performance, then a strong case for increasing financial inclusion can be made. Indeed, the available evidence indicates that greater levels of financial inclusion promote bank credit to the private sector (DeHan, 2016).

The rest of the paper is organized as follows. In section two, we provide a brief review of the relevant literature. In sections 3 and 4, we discuss the data and methodology, and present and discuss the empirical results. Finally, section 5 summarizes and concludes the paper.

\section{FINANCIAL DEVELOPMENT, BANK PERFORMANCE AND FINANCIAL INCLUSION}

On average, the finance-growth literature argues that financial development contributes to economic growth. For example, as one common measure of financial development, bank credit to the private sector to GDP ratio increases the supply of capital and facilitates the allocation of financial resources to their productive activities. Given this possibly positive impact, the literature contains numerous papers which examine the determinants of financial development at both cross-country and within-country levels.

The early literature on financial development is due to the classical writings of McKinnon (1973) and Shaw (1973) who argued that financial development can be hindered by government restrictions such as interest rate ceilings, and reserve and liquidity requirements. This is why they both propose financial liberalization and less government interventions in the financial system can promote financial development. Relative to this argument, one of the early papers that examined the impact of financial liberalization of financial development is Arestis et al. (2002). Based on the time period 1955-1997, and a total of six developing economies, Aretis et al. (2002) find that the impact of financial liberalization on financial development varies considerably across countries.

The role of trade openness (exports plus imports to GDP ratio) in impacting financial development has also been examined by Rajan and Zingales (2003) who argue that vested interests resist financial development because they are worried by the threat of new (and competing) market entrants. Again, this theoretical argument was examined empirically by Law and Demetriades (2004). Based on a total of 43 developing countries (1980-2000), and dynamic panel data techniques, their results support the hypothesis put forward by Rajan and Zingales (2003). In other words, the simultaneous opening of capital flows and trade promote financial development. In addition, their findings support the view that institutional quality is a significant determinant factor of financial development.

In addition to financial liberalization and openness, a number of models have been proposed to analyze the relationship between real economic growth and financial development. Some of the well-known models that argue financial development impacts growth are due to Pagano (1993) and King and Levine (1993). The opposite view was held by Robinson (1952). In addition, it is also argued that financial development and growth are mutually dependent (Berthelemy and Varoudakis, 1996). Finally, and to make matter even more confusing, it is argued that finance and growth might evolve independently of each other (Chandavarkar 1992).

As expected, the theoretical papers that dealt with the determinants of financial development has led to the publication of numerous empirical papers. These papers can be classified under two groups. The first group relies on cross-country data and, on average, estimate one version of the following model:

$\mathrm{FD}_{\mathrm{i}, \mathrm{t}}=\alpha_{\mathrm{i}}+\mathrm{GROWTH}_{\mathrm{it}}+\mathrm{X}_{\mathrm{it}} \beta+\varepsilon_{\mathrm{i}, \mathrm{t}} \quad \mathrm{i}=1, \ldots, \mathrm{n}, \mathrm{t}=1, \ldots, \mathrm{T}$

where, $F D_{i, t}$ is the financial development measure (bank credit to the private sector to GDP ratio) for country $i$ at time $t$, with $\mathrm{i}=1, \ldots . ., \mathrm{T}, \alpha$ is the constant term, and $\mathrm{X}_{\mathrm{it}}$ represents the vector of $\mathrm{k}$ explanatory variables, and $\varepsilon$ is the disturbance term. Some of the main explanatory variables include inflation, openness (exports and imports to GDP ratio), real GDP growth rate, foreign direct investment (FDI), and foreign exchange deposits.

The second group of empirical papers relies on within-country data. In other words, these papers use time series econometric techniques (co-integration, Vector Error Correction Model, and Granger Causality) to examine the determinants of financial development. Some of the more recent papers include Hamdi (2015), Almarzoqi (2015), Cherif and Dreger, 2016), Heng et al. (2016), Le et al. (2016), and others.

The performance of individual banks has also been examined in the literature. Most of these empirical works examine the determinants of bank performance (Return on assets) and net interest margin. Following the publication of the classical papers by Demirguc-Kunt and Huizinga (1999) and Demirguc-Kunt and Huizinga (2001), numerous examine the performance of banks at the country-level. Some of the more recent papers include Chortareas et al. (2011), Naceur and Omran (2011), Fungacová and Poghosyan (2011), Gurbuz et al. (2013), Trujillo-Ponce (2013), Nassar et al (2014), Helhel (2015), and Hashem (2016). 
In addition to the above-mentioned papers that examine bank performance, it is important to note that the banking and finance literatures also examine the impact of foreign exchange deposits on the performance of banks. This issue (dollarization) is important due to the fact that in dollarized economies, banks are exposed to two special risk sources and these are liquidity risk and solvency risk.

Banks with greater proportions of their deposits in foreign exchange are exposed to greater levels of liquidity risk. In the case of deposits in the local currency, central banks can act as the "lender of the last resort" and naturally, this ability is not possible in the case of foreign currency deposits. As a result, when foreign exchange deposits increase, managers tend to hold more liquid positions, or to finance less risky projects. Together, such behaviour would decrease banks' profitability (Rengifo et al. (2010). It can also be argued that foreign currency deposits would pressure the balance sheets of banks when a devaluation (or depreciation) of the local currency occurs. Again, banks that have proportions of their deposits in foreign currencies are more likely to increase their reserves against any possible loan losses (Chang and Velasco, 2001).

Due to the above-mentioned arguments, foreign exchange deposits can impact the development of banking systems. Indeed, the literature includes a growing number of papers that examine this issue. Some of these papers are Kubo (2007), Kutan et al. (2010), Viera et al. (2012), and Catao et al. (2016). On average, and as expected, greater levels of dollarization impact bank performance.

The concept of financial inclusion can be measured along several dimensions. These dimensions can rely on accessibility, usage, quality, and impact (Bank for International Settlements (2015). Irrespective of what dimensions are used, the available data on financial inclusion is classified into supply-side and demand-side.

The sources of supply-side indicators are those who provide financial services themselves and include measures like total number of bank branches, ATMs, and loan and deposit accounts, normalized by population. The demand-side indicators, on the other hand, are survey-based indicators. Published by the World Bank, for example, the Global Findex indicators addresses five basic dimensions of the use of financial services on the individual level, and these are accounts, savings, borrowing, payment patterns, and insurance. One of the most-used measures is the percentage of adults with an account at a formal financial institution.

The issue of financial inclusion is important for several reasons. First, it is stated that "our estimates offer evidence of a strong correlation between financial access and poverty rates" (Park and Mercado, 2015). Second, it is stated that "the model simulations also indicate that different dimensions of financial inclusion unambiguously increase the economy's TFP as talented entrepreneurs, who desire to operate firms on a larger scale, benefit disproportionately" (Dabla-Norris et al., 2015). Finally, it is argued that "greater inclusion should make interest rates more effective as a policy tool and it may facilitate central banks' effort to maintain price stability" (Mehrota and Yetman, 2015).

Based on the fact that greater financial inclusion levels have a number of positive implications, the literature examines what determines financial inclusion itself. On average the literature which examines the determinants of financial inclusion at the country-level, performs probit estimations using the following expression:

$X_{i}=\alpha+\beta^{*}$ Gender $_{i}+\delta *$ Age $_{i}+\phi *$ Income $_{i}+\rho *$ Education $_{i}+\varepsilon_{i}$

where, $\mathrm{X}$ is the financial inclusion variable (equal to one if the individual has an account and zero otherwise). The rest of the variables are gender (one if a woman and zero otherwise), age (number of years and its squared value), income (four dummy variables for the poorest $20 \%$, second $20 \%$, third $20 \%$, and fourth $20 \%$ ), and education (two dummy variables for those with secondary education and tertiary education).

Some of the papers that used the above methodology include Allen (2012), Fungacova and Weill (2014), Tuesta etal. (2015), Allen et al. (2016), and Zins and Weill (2016). For example, based on their analysis of 148 countries, Demirgüc-Kunt and Klapper (2013) show that differences in income among countries and among individuals within countries affect the level of financial inclusion.

\section{THE DATA AND METHODOLOGY}

As mentioned in the introduction, this paper examines three inter-related issues and these are the determinants of financial development at the macro-level, determinants of bank performance (micro-level), and the determinants of financial inclusion in Jordan. To examine the determinants of financial development in Jordan, we specify model (1):

$\mathrm{BC}_{\mathrm{t}}=\lambda+\beta$ GROWTH $_{\mathrm{t}}+\psi$ OPENNESS $_{\mathrm{t}}+\phi$ INFLATION $_{\mathrm{t}}+\zeta$ FOREIGNEXC $_{\mathrm{t}}+\varepsilon_{\mathrm{t}}$

where, $B C$ is equal to bank credit to the private sector to GDP ratio, GROWTH is real GDP growth rate, OPENNESS is exports plus imports to GDP ratio, INFLATION stands for the consumer price index, and FOREIGNEXC is equal to foreign exchange deposits to total bank deposits. The expected signs of the parameters are: $\lambda>0, \beta>0, \psi>0, \phi<0, \zeta<0$. The error term $(\varepsilon)$ is assumed to be independently and identically distributed. Finally, the subscript $(t)$ denotes time (1982-2015). 
As commonly known in such exercises, before we estimate the above expression (1), we proceed as follows. First, the nature of the data distribution is examined using standard descriptive statistics including mean, median, and standard deviation. Second, the time series properties of all the used variables are tested for their stationarity using both the DickeyFuller and Phillips-Perron tests. Third, the co-integrating relationship among the variables is examined using the JohansenMasulius procedures. In other words, the co-integrating rank $(r)$ is formally tested using the maximum eigenvalue $\left(\lambda_{\max }\right)$ and the trace test $\left(\lambda_{\text {trace }}\right)$. These values are computed as follows:

$\lambda_{\max }=-\mathrm{T} \log \left(1-\lambda_{\mathrm{r}+1}\right)$

where the suitable null is $r=g$ co-integrating vectors with $(g=0,1,2,3, \ldots)$ against the alternative which is $r \leq g+1$.

$\lambda_{\text {trace }}=-\mathrm{T} \sum_{\mathrm{I}=\gamma+1}^{\mathbb{R}} \log \left(1-\lambda_{\mathrm{i}}\right)$

where, the null is $r=\mathrm{g}$ against the general specification $r \leq 1$.

Fourth, based on the co-integration results, a vector error-correction (VEC) model is estimated to examine the long-run and short-run causality dynamics.

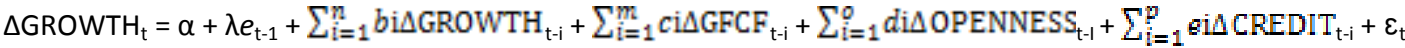

In the above expression (4), we can state that a long-run convergence does occur between the variables if the parameter $(\lambda)$ of the error correction term is negative and statistically significant.

Finally, we estimate Granger causality between our dependent variable and each of the independent variables. Using expression (4), changes in openness, inflation, and foreign exchange Granger cause financial development (BC) if the $c_{i}^{\prime}{ }^{\prime}$, $d_{i}^{\prime} s, e_{i}^{\prime} s, f_{i}^{\prime} s$ are statistically significant.

As far as the performance of banks is concerned, we estimate the following panel regression models ( 5 and 6 ):

$R^{R O A}{ }_{i, t}=\beta_{1} F_{i, t}+\beta_{2}$ RETAIL $_{i, t}+\beta_{3}$ BONDS $_{i, t}+\beta_{4}$ EQUITY $_{i, t}+\beta_{5}$ SIZE $_{i, t}+\beta_{6}$ COM $_{t}+\beta_{8}$ OVERHEAD $_{t}+\varepsilon_{i, t}$

$N_{I M}, t=\beta_{1} F_{i, t}+\beta_{2}$ RETAIL $_{i, t}+\beta_{3}$ BONDS $_{i, t}+\beta_{4}$ EQUITY $_{i, t}+\beta_{5}$ SIZE $_{i, t}+\beta_{6}$ COM $_{t}+\beta_{8}$ OVERHEAD $_{t}+\varepsilon_{i, t}$

where, the subscripts $i$ and $t$ denote banks $(i=1, \ldots, 13)$ and time $(t=1, \ldots, T=2008-2015)$ respectively.

The dependent variables are return on assets (ROA) which is equal to net income divided by total assets and net interest margin (NIM) which is equal to [Interest income - Interest expense] / Total assets].

The independent variables include the ratio of foreign exchange deposits to total deposits (FE), the ratio of credit to individuals to total credit (RETAIL), bank investment in bonds to total assets (BONDS), equity capital to total assets (EQUITY), the natural logarithm of total assets (SIZE), net commission income to total operating income (COM, and total operating expenses to total assets (OVERHEAD).

To estimate the above models ( 5 and 6 ), the estimation method that we use is the Period Seemingly Unrelated Regression (SUR) - Pooled Estimated Generalized Least Squares (EGLS). This method corrects for the arbitrary period serial correlation and the period heteroskedasticity between the residuals for a given cross-section.

Finally, to examine the determinants of financial inclusion, we perform probit estimation using the following expression:

$X_{i}=\alpha+\beta^{*}$ Gender $_{i}+\delta^{*}$ Age $_{i}+\phi^{*}$ Income $_{i}+\rho^{*}$ Education $_{i}+\varepsilon_{i}$

where $\mathrm{X}$ is the financial inclusion variable (equal to one if the individual has an account and zero otherwise). The rest of the variables are gender (one if a woman and zero otherwise), age (number of years and its squared value), income (four dummy variables for the poorest $20 \%$, second $20 \%$, third $20 \%$, and fourth $20 \%$ ), and education (two dummy variables for those with secondary education and tertiary education).

\section{THE EMPIRICAL RESULTS}

In Table 1, we report the descriptive statistics of the determinants of financial development in terms of their basic values. Based on the reported values, we can make two observations. First, the mean-to-median ratio for each variable is equal to nearly one and this confirms normality. Second, during the period 1982-2015, while openness reflect the highest standard deviation, bank credit to the private sector to GDP ratio and foreign exchange deposits to total deposits reflect some significant variability. 
Table 1: Descriptive Statistics of Financial Development (1982-2015)

$B C$ is equal to bank credit to the private sector to GDP ratio, GROWTH is real GDP growth rate, OPENNESS is exports plus imports to GDP ratio, INFLATION stands for the consumer price index, and FOREIGNEXC is equal to foreign exchange deposits to total bank deposits.

\begin{tabular}{|l|l|l|l|l|l|}
\hline Variable & Mean & Median & Maximum & Minimum & Std Dev. \\
\hline BC & 0.655 & 0.657 & 0.857 & 0.499 & 0.080 \\
\hline GROWTH & 0.038 & 0.038 & 0.143 & -0.107 & 0.041 \\
\hline OPENNESS & 0.837 & 0.841 & 1.176 & 0.494 & 0.157 \\
\hline INFLATION & 0.047 & 0.036 & 0.256 & -0.009 & 0.051 \\
\hline FOREIGNEXC & 0.300 & 0.313 & 0.414 & 0.168 & 0.089 \\
\hline
\end{tabular}

Table 2 presents the results of the unit root tests. These results reveal that all variables are non-stationary at the level form and stationary at their first differences. This implies that all variables are integrated in the same order at their first differences. This conclusion indicates that we can apply the Johansen co-integration test to detect the long-term cointegrating relationship among our group of variables.

\section{Table 2: Augmented Dickey-Fuller Unit Root Test}

$B C$ is equal to bank credit to the private sector to GDP ratio, GROWTH is real GDP growth rate, OPENNESS is exports plus imports to GDP ratio, INFLATION stands for the consumer price index, and FOREIGNEXC is equal to foreign exchange deposits to total bank deposits.

\begin{tabular}{|l|l|l|l|l|l|l|l|}
\hline Variable & \multicolumn{3}{|c|}{ Level } & \multicolumn{3}{c|}{ First-Difference } \\
\hline & None & Constant & $\begin{array}{l}\text { Constant \& } \\
\text { Trend }\end{array}$ & None & Constant & $\begin{array}{l}\text { Constant } \\
\text { Trend }\end{array}$ \\
\hline BC & 0.805 & -2.167 & -3.120 & $-5.166^{*}$ & $-5.249^{*}$ & $-5.389^{*}$ \\
\hline GROWTH & $-3.001^{*}$ & $-4.346^{*}$ & $-4.650^{*}$ & $-10.118^{*}$ & $-9.951^{*}$ & $-9.801^{*}$ \\
\hline OPENNESS & -0.489 & -1.727 & -2.026 & $-4.551^{*}$ & $-4.477^{*}$ & $-4.413^{*}$ \\
\hline INFLATION & -2.187 & -3.469 & -3.523 & $-6.676^{*}$ & $-6.576^{*}$ & $-6.472^{*}$ \\
\hline FOREIGNEXC & -0.231 & -1.416 & -1.078 & $-4.760^{*}$ & $-4.682^{*}$ & $-5.123^{*}$ \\
\hline *Significant at the 99 percent confidence level.
\end{tabular}

In Tables 3 and 4, we report the results of the Johansen co-integration test. Again, based on the reported results of both the trace and maximum eigenvalue statistics, we can conclude that there are at least two co-integrating relationships at the 5 percent significance level. Such results reveal the presence of a long-run relationship among our group of variables. In addition, this result implies that we can estimate a Vector Error Correction Model (VEC).

Table 3: Johansen Multivariate Co-Integration Test

\begin{tabular}{|l|l|l|l|l|}
\hline Hypothesized No. of CE(s) & Eigen Value & Trace Statistic & 5 percent CV & P-Value \\
\hline None* & 0.618 & 71.370 & 60.061 & 0.004 \\
\hline At most 1* & 0.609 & 40.557 & 40.174 & 0.046 \\
\hline At most 2 & 0.183 & 10.467 & 24.276 & 0.823 \\
\hline
\end{tabular}

Table 4: Johansen Multivariate Co-Integration Test

\begin{tabular}{|l|l|l|l|l|}
\hline Hypothesized No. of CE(s) & Eigen Value & Trace Statistic & 5 percent CV & P-Value \\
\hline None* & 0.618 & 30.813 & 30.439 & 0.045 \\
\hline At most 1* & 0.609 & 30.090 & 24.159 & 0.007 \\
\hline At most 2 & 0.183 & 6.463 & 17.797 & 0.860 \\
\hline \multicolumn{2}{|l}{} \\
\hline
\end{tabular}

The regression results under the VEC model with two lags are presented in Table 5 below.

Table 5: Estimates of VEC Model

$B C$ is equal to bank credit to the private sector to GDP ratio, GROWTH is real GDP growth rate, OPENNESS is exports plus imports to GDP ratio, INFLATION stands for the consumer price index, and FOREIGNEXC is equal to foreign exchange deposits to total bank deposits.

\begin{tabular}{|l|l|l|l|}
\hline Variable & Coefficient & Std. Error & t-statistic \\
\hline$\lambda e_{\mathrm{t}-1}$ & -0.126 & 0.134 & $-1.935^{*}$ \\
\hline$\Delta \mathrm{BC}(-1)$ & -0.052 & 0.222 & -0.234 \\
\hline$\Delta \mathrm{BC}(-2)$ & -0.332 & 0.241 & $-1.375^{*}$ \\
\hline$\Delta \mathrm{GROWTH}(-1)$ & -0.032 & 0.487 & -0.066 \\
\hline$\Delta$ GROWTH(-2) & -0.176 & 0.268 & -0.658 \\
\hline
\end{tabular}




\begin{tabular}{|l|l|l|l|}
\hline$\triangle$ OPENNESS(-1) & 0.150 & 0.120 & $1.249^{*}$ \\
\hline$\triangle$ OPENNESS(-2) & 0.059 & 0.092 & 0.643 \\
\hline$\Delta$ INFLATION(-1) & 0.114 & 0.258 & 0.439 \\
\hline$\Delta$ INFLATION(-2) & -0.056 & 0.199 & -0.281 \\
\hline$\Delta$ FOREIGNEXC(-1) & 0.003 & 0.259 & 0.010 \\
\hline$\Delta$ FOREIGNEXC(-2) & -0.326 & 0.225 & $-1.449^{*}$ \\
\hline Adjusted R-Squared & 0.462 & & \\
\hline F-Statistic & 14.031 & & \\
\hline *Significant at the 99 percent confidence level. & & \\
\hline
\end{tabular}

These results confirm the existence of a long-run equilibrium relationship among our variables. This is confirmed by the negative and significant value of the coefficient $(\lambda)$ of the error correction term $\left(\lambda e_{t-1}\right)$. Furthermore, this finding also implies that real economic growth, openness, inflation, and foreign exchange deposits jointly promote financial development.

Relative to the above findings, it is also useful to note that the results of the variance decomposition analysis reveal that the variability in financial development (bank credit to the private sector to GDP ratio) is largely lagged by its own variance (Table 6). However, what is more important and interesting to note is the observation that real GDP growth rate (GROWTH) reflects the strongest power in explaining the variability in financial development (BC) over time. On the other hand, openness, inflation, and foreign exchange deposits reflect only weak evidence in explaining the variability of bank credit. This can be seen from these variables reported values over time.

Table 6: Varience Decomposition of FD

FD is equal to bank credit to the private sector to GDP ratio, GROWTH is real GDP growth rate, OPENNESS is exports plus imports to GDP ratio, INFLATION stands for the consumer price index, and FOREIGNEXC is equal to foreign exchange deposits to total bank deposits.

\begin{tabular}{|c|l|l|l|l|l|}
\hline Period & FD & GROWTH & OPENNESS & INFLATION & FOREIGNEXC \\
\hline 1 & 100.000 & 0.000 & 0.000 & 0.000 & 0.000 \\
\hline 2 & 91.063 & 5.437 & 1.746 & 1.613 & 0.140 \\
\hline 3 & 92.307 & 4.203 & 1.438 & 1.246 & 0.806 \\
\hline 4 & 89.614 & 6.309 & 1.360 & 1.794 & 0.922 \\
\hline 5 & 89.453 & 6.249 & 1.202 & 1.698 & 1.397 \\
\hline 6 & 89.569 & 6.363 & 1.074 & 1.544 & 1.449 \\
\hline 7 & 90.427 & 5.707 & 1.055 & 1.468 & 1.341 \\
\hline 8 & 90.774 & 5.599 & 0.961 & 1.341 & 1.322 \\
\hline 9 & 90.626 & 5.584 & 0.915 & 1.484 & 1.390 \\
\hline 10 & 90.555 & 5.810 & 0.837 & 1.399 & 1.397 \\
\hline
\end{tabular}

Table 7: Pairwise Granger Causality Tests

\begin{tabular}{|l|l|l|}
\hline Null Hypothesis & F-Statistic & Probability \\
\hline GROWTH does not Granger cause FD & 2.979 & 0.068 \\
\hline FD does not Granger cause GROWTH & 0.349 & 0.708 \\
\hline OPENNESS does not Granger cause FD & 1.026 & 0.372 \\
\hline FD does not Granger cause OPENNESS & 1.176 & 0.324 \\
\hline INFLATION does nor Granger cause FD & 1.365 & 0.275 \\
\hline FD does not Granger cause INFLATION & 2.029 & 0.151 \\
\hline FOREIGNEXC does not Granger cause FD & 1.139 & 0.335 \\
\hline FD does not Granger cause FOREIGNEXC & 1.686 & 0.204 \\
\hline
\end{tabular}

As far as the short-run relationship is concerned, it must be noted that except for real economic growth, none of the independent variables seem to significantly Granger cause bank credit and this can be seen in Table 7 above.

The results of the performance of our 13 Jordanian banks are presented in Tables 8-12 inclusive. In Table 8, we report some descriptive statistics for both the dependent and independent variables.

First, during the period 2008-2015, the mean value of bank profitability (ROA) and net interest margin (NIM) were equal to 1.29 percent and 3.01 percent respectively. In relative terms, the mean value of net interest margin is relatively high. For example, this measure is equal to 0.8 percent in Luxemburg, 1.6 percent in Finland, 2.9 percent in Germany, and 1.07 percent (Kasman et al., 2014).

Second, the standard deviations of bank size (SIZE), credit to the corporate and retail sectors, and foreign exchange reflect the largest variations among the sample of banks. For example, the standard deviation of the natural logarithm of total 
assets is equal to 1.0238 and this is much higher than, for example, the standard deviation of commission income as a proportion of total assets (0.0026).

Finally, it is important to note that the mean ratio of foreign exchange deposits to total deposits was equal to 26.16 percent. Whilst this proportion is high, it is not really as high as that which prevails in, for example, Lebanon (more than 150 percent), and in Egypt (about 90 percent).

\section{Table 8: Bank Performance Descriptive Statistics}

ROA stands for return on assets (net income divided by total assets), NIM is net interest margin which is equal to [Interest income Interest expense] / Total assets. The independent variables are the ratio of foreign exchange deposits to total deposits (FE), ratio of credit to individuals to total credit (RETAIL), ratio of credit to SMEs to total credit (SME), ratio of credit to the corporate sector to total credit (CORPORATE), bank investment in bonds to total assets (BONDS), equity capital to total assets (EQUITY), natural logarithm of total assets (SIZE), net commission income to total operating income (COM), and total operating expenses to total assets (OVERHEAD).

\begin{tabular}{|l|l|l|l|l|l|}
\hline & MEAN & MEDIAN & MAXIMUM & MINIMUM & STD.DEV. \\
\hline ROA & 0.0129 & 0.0139 & 0.0251 & -0.002 & 0.0050 \\
\hline NIM & 0.0301 & 0.0300 & 0.0440 & 0.0149 & 0.0064 \\
\hline FE & 0.2616 & 0.2766 & 0.6488 & 0.0010 & 0.1352 \\
\hline RETAIL & 0.1917 & 0.1694 & 0.5428 & 0.0108 & 0.1349 \\
\hline SME & 0.0932 & 0.0884 & 0.2968 & 0.0000 & 0.0585 \\
\hline CORPORATE & 0.4623 & 0.4423 & 0.8325 & 0.1185 & 0.1721 \\
\hline BONDS & 0.2189 & 0.2117 & 0.3662 & 0.0222 & 0.0673 \\
\hline EQUITY & 0.0788 & 0.0707 & 0.2086 & 0.0218 & 0.0387 \\
\hline SIZE & 21.3216 & 21.3089 & 23.9759 & 19.4353 & 1.0238 \\
\hline COM & 0.0068 & 0.0065 & 0.0200 & 0.0016 & 0.0026 \\
\hline OVERHEAD & 0.0252 & 0.0252 & 0.0429 & 0.0101 & 0.0064 \\
\hline
\end{tabular}

The estimation results of models 5 and 6 are reported in Tables 9-11 inclusive. Again, based on these results, the following comments can be provided.

\section{Table 9: Regression Results of Retail Credit}

ROA stands for return on assets (net income divided by total assets), NIM is net interest margin which is equal to [Interest income Interest expense] / Total assets. The independent variables are the ratio of foreign exchange deposits to total deposits (FE), ratio of credit to individuals to total credit (RETAIL), ratio of credit to SMEs to total credit (SME), ratio of credit to the corporate sector to total credit (CORPORATE), bank investment in bonds to total assets (BONDS), equity capital to total assets (EQUITY), natural logarithm of total assets (SIZE), net commission income to total operating income (COM), and total operating expenses to total assets (OVERHEAD)

\begin{tabular}{|c|c|c|c|c|}
\hline Variable & Dependent & BOA & Depender & $\mathrm{IM}$ \\
\hline & Coefficient & t-Statistic & & \\
\hline $\mathrm{FE}$ & 0.0124 & $4.4424^{*}$ & 0.0149 & $4.6154^{*}$ \\
\hline RETAIL & 0.0100 & $2.4715^{* *}$ & 0.0165 & $3.1591^{*}$ \\
\hline BONDS & -0.0029 & -0.7737 & -0.0196 & -4.3261 \\
\hline EQUITY & 0.0001 & 0.0120 & 0.0090 & 0.6731 \\
\hline SIZE & 0.0008 & $9.7308^{*}$ & 0.0009 & $9.3627^{*}$ \\
\hline $\mathrm{COM}$ & 0.2284 & $1.6984^{* * *}$ & -0.4272 & $-2.9953^{\circ}$ \\
\hline OVERHEAD & -0.3729 & $-8.5578^{*}$ & 0.3906 & $8.6297^{*}$ \\
\hline Adj. R-Squared & 0.7440 & Adj. R-Squared & 0.8547 & \\
\hline F-Statistic & $50.8844^{*}$ & F-Statistic & 102.0123 & \\
\hline D-W Statistic & 1.9246 & D-W Statistic & 1.8952 & \\
\hline
\end{tabular}

First, the sign of the coefficient of foreign exchange (FE) is positive and significant in both equations. In other words, foreign exchange deposits impact bank profitability (ROA) in a positive manner. However, this positive impact comes at the expense of widening net interest margin. This result is what one would expect as lending in foreign exchange incurs greater levels of risk, and hence the wider net interest margins. Furthermore, it is known that minimum reserve requirement on foreign exchange deposits is always higher than that on local currency deposits. 
Second, retail banking positively impacts bank profitability. The sign of this coefficient is equal to +0.010 and statistically significant (Table 9). In addition, the more banks get involved in this sector (retail), the wider net interest margin becomes. Again, the sign of this coefficient is equal to +0.0165 . These results are not surprising. It is a fact that banks incur higher administrative costs when they deal more with the retail end of the market. However, this extra cost can be passed on to their customers. In addition, it is known that the turnover of business in the retail sector is higher, and as a result, banks that lend more to individuals seem tend to earn higher returns on their assets.

Third, as far as the impact of overhead expenses on profitability is concerned, the sign of this coefficient is negative (0.3729). This finding implies that less efficient banks realize lower accounting returns. However, at least part of this inefficiency is passed on to customers in the form of wider net interest margin. This can be seen by the positive coefficient of overhead expenses on net interest margin (+0.3906).

Fourth, banks that rely more on commission income (more diversified sources of income) tend to achieve higher profits. Interestingly, the impact of this diversification aspect on net interest margin is negative (-0.4727). This indicates that banks with more diversified sources of income pass on this advantage on to their customers by narrowing their interest margins.

Fifth, listed Jordanian banks do not benefit from economies of scale. While the impact of bank size (SIZE) on return on assets is positive, this significant impact come at the expense of its positive impact on also net interest margin.

Finally, the impact of banks' investment in government securities (BONDS) on return on assets and on net interest margin is consistently negative. This is expected given the relatively low interest rate on this asset and its low turnover ratio. With in this context, one wonders why the government has so far not developed a liquid government (and corporate) securities market.

In addition to the above analysis, we re-estimate our main models to include credit to the SME sector and corporate sector. The results of this analysis are reported in Tables 10 and 11. Here, we have three observations.

Table 10: Regression Results of SME Credit

ROA stands for return on assets (net income divided by total assets), NIM is net interest margin which is equal to [Interest income Interest expense] / Total assets. The independent variables are the ratio of foreign exchange deposits to total deposits (FE), ratio of credit to individuals to total credit (RETAIL), ratio of credit to SMEs to total credit (SME), ratio of credit to the corporate sector to total credit (CORPORATE), bank investment in bonds to total assets (BONDS), equity capital to total assets (EQUITY), natural logarithm of total assets (SIZE), net commission income to total operating income (COM), and total operating expenses to total assets (OVERHEAD).

\begin{tabular}{|l|l|l|l|l|}
\hline Variable & \multicolumn{2}{|l|}{ Dependent Variable: ROA } & \multicolumn{2}{l|}{ Dependent variable: NIM } \\
\hline & Coefficient & t-Statistic & & \\
\hline FE & 0.01123 & $4.1520^{*}$ & 0.0183 & $7.6955^{*}$ \\
\hline SME & -0.0149 & $-2.6660^{*}$ & -0.0256 & $-6.1931^{*}$ \\
\hline BONDS & -0.0010 & -0.2341 & -0.0133 & $-3.7764^{*}$ \\
\hline EQUITY & 0.0088 & 0.8409 & 0.0060 & 0.6272 \\
\hline SIZE & 0.0007 & $8.6905^{*}$ & 0.0010 & $13.5692^{*}$ \\
\hline COM & 0.3768 & $2.6589^{*}$ & -0.4211 & $-4.0162^{*}$ \\
\hline OVERHEAD & -0.2868 & -5.9437 & 0.4899 & $15.8971^{*}$ \\
\hline Adj. R-Squared & 0.7567 & Adj. R-Squared & 0.8709 & \\
\hline F-Statistic & $54.3835^{*}$ & F-Statistic & 574.1039 & \\
\hline D-W Statistic & 1.8302 & D-W Statistic & 1.8370 & \\
\hline$*, * *, * * *$ imply significance at the 99, 95, and 90 percent confidence levels respectively. \\
\hline
\end{tabular}

\section{Table 11: Regression Results of Corporate Credit}

ROA stands for return on assets (net income divided by total assets), NIM is net interest margin which is equal to [Interest income Interest expense] / Total assets. The independent variables are the ratio of foreign exchange deposits to total deposits (FE), ratio of credit to individuals to total credit (RETAIL), ratio of credit to SMEs to total credit (SME), ratio of credit to the corporate sector to total credit (CORPORATE), bank investment in bonds to total assets (BONDS), equity capital to total assets (EQUITY), natural logarithm of total assets (SIZE), net commission income to total operating income (COM), and total operating expenses to total assets (OVERHEAD).

\begin{tabular}{|l|l|l|l|l|}
\hline Variable & \multicolumn{2}{|l|}{ Dependent Variable: ROA } & \multicolumn{2}{l|}{ Dependent variable: NIM } \\
\hline & Coefficient & t-Statistic & & \\
\hline FE & 0.0127 & $4.5314^{*}$ & 0.0169 & $5.3985^{*}$ \\
\hline CORPORATE & -0.0018 & -0.7404 & 0.0003 & 0.1107 \\
\hline BONDS & -0.0016 & -0.3818 & -0.0132 & $-2.8966^{*}$ \\
\hline EQUITY & 0.0045 & 0.4077 & 0.01566 & 1.1358 \\
\hline SIZE & 0.0007 & $8.3642^{*}$ & 0.0008 & $8.4064^{*}$ \\
\hline COM & 0.2771 & $1.9462^{* *}$ & -0.4556 & $-3.1069^{*}$ \\
\hline
\end{tabular}




\begin{tabular}{|l|l|l|l|l|}
\hline OVERHEAD & --0.2785 & $-5.9262^{*}$ & 0.4955 & $10.3901^{*}$ \\
\hline Adj. R-Squared & 0.7199 & & 0.9004 & \\
\hline F-Statistic & 45.1312 & F-Statistic & 156.2983 & \\
\hline D-W Statistic & 1.9116 & D-W Statistic & 1.8068 & \\
\hline$*, * *, * * *$ imply significance at the 99,95, and 90 percent confidence levels respectively. \\
\hline
\end{tabular}

First, the reported results (Table 10) show that credit to the SME sector impacts bank profitability and bank net interest margin negatively. As mentioned previously, this is due to the fact that the turnover of this business is much lower than the retail sector. As far as the other independent variables are concerned, the signs of their coefficient do not really change.

Second, the reported results (Table 11) show that credit to the corporate sector has no impact on either bank profitability or on net interest margin. Again, this is probably due to the even lower turnover in this sector. In addition, and similar to the above, the signs and significance of the other independent variables do not change in any significant manner.

Finally, we report in Table 12 the results and marginal effects of the probit estimations for financial inclusion. Here, we can conclude that all individual characteristics have a significant relation with financial inclusion. Being a woman significantly reduces the probability of having a formal account at a financial institution. Similarly, older people are more likely to be financially included. Relative to this point, it is useful to note that when we included the square of age in the model (to check for non-linearity), its coefficient turned out to be not significant.

The reported results also reveal that greater income is associated with more inclusion. Moreover, it is also useful to note that the dummy variables for income have larger coefficients for the lower income quintiles. This reflects that as income increases, the likelihood of having an account increases. Education is positively associated with inclusion. In other words, the more educated a person is the more likely he or she to be financially included. Finally, based on the reported marginal effects, it can be argued that education and income are the most important individual characteristics that impact financial inclusion. This conclusion, in actual fact, is consistent with the international evidence. Indeed, these characteristics are also the most important factors impacting inclusion in Africa and China (Fungacova and Weill, 2015).

Table 12: Determinants of Financial Inclusion

\begin{tabular}{|l|l|l|}
\hline Variable & Coefficient & Marginal Effects \\
\hline Gender & $-1.2928^{*}$ & 0.430 \\
\hline Age & $+0.045^{*}$ & 0.015 \\
\hline Income - Poorest 20\% & $-1.215^{*}$ & 0.405 \\
\hline Income - Second 20\% & $-1.145^{*}$ & 0.382 \\
\hline Income - Third 20\% & $-0.991^{*}$ & 0.330 \\
\hline Income - Fourth 20\% & $-0.371^{*}$ & 0.123 \\
\hline Secondary Education & $+1.065^{*}$ & 0.355 \\
\hline Tertiary Education & $+2.227^{*}$ & 0.742 \\
\hline Pseudo R & 0.342 & \\
\hline Log Likelihood & 958.326 & \\
\hline * implies significance at the 99 percent level. & \\
\hline
\end{tabular}

\section{SUMMARY AND CONCLUSIONS}

It is probably accurate to state that financial development in general, and banking sector development in particular, promote economic growth, reduce poverty, and enhance income equality. Indeed, these benefits stem from the fact that efficient banks provide their respective economies with a myriad of economically useful function.

Given that finance is important, the financial economics literature contains numerous papers that examine various aspects related to financial development. Some of these aspects include the determinants of financial development (measured by the ratio of bank credit to GDP ratio) at the macro-level, determinants of bank performance (measured by return on assets and net interest margin), and the determinants of financial inclusion (measured by the proportion of the adult population with a formal bank account).

Relative to the above, this paper examined three issue and these are:

(1) The determinants of financial development in Jordan during the period 1982-2015.

(2) The impact of foreign exchange deposits and retail banking (and other factors) on the performance banks (2008-2015). 
(3) The determinants of financial inclusion in Jordan.

Based on the used econometric techniques, the empirical results indicate a number of conclusions.

First, while the variability in financial development is found to be largely lagged by its own variance, real GDP growth rate reflects the strongest power in explaining the variability in financial development over time. In addition, it is reported that openness, inflation, and foreign exchange deposits reflect weak evidence in explaining the variability of bank credit.

Second, foreign exchange deposits impact bank performance in a somewhat predictable manner. Indeed, the impacts of foreign exchange deposits on bank profitability and on net interest margin are positive. This finding implies that banks with greater proportions of their deposits in the form of foreign exchange tend to widen their interest margins (due to the extra risk) and achieve superior accounting performance.

Third, the impacts of retail banking on bank profitability and on net interest margin are also positive. This result is in stark contrast with the impact of credit to the SME and corporate sectors. Again, and notwithstanding the extra administrative costs, this finding implies that retail banking tends to benefit banks, and this benefit is due to the high turnover that retail banking brings.

Finally, the probit results indicate that all individual characteristics (gender, age, income, and education) are important factors in impacting financial inclusion.

Based on our findings, a number of policy recommendations and future research options can be provided.

First, it is in the interest of the banking system in Jordan to promote financial inclusion at the national level. Indeed, this aspect is important to, not only the concerned individuals, but also to their performance. Moreover, with greater levels of financial inclusion, net interest margin might also decrease.

Second, as far as the foreign exchange deposits are concerned, their weak impact on financial development and on bank performance (widening net interest margin) is disappointing. The Central Bank of Jordan (CBJ) and commercial banks themselves must look into various policies that result in greater investment of these deposits. Within this context, why not look into issuing local development bonds in foreign exchange? In addition, based on some detailed analysis, the CBJ might be able to consider reducing foreign exchange minimum reserve requirements.

Finally, the fact that financial development and banking literature covers a wide array of topics, future research effort can examine a number of issues. For example, the determinants of financial development using different measures like stock market capitalization to GDP ratio. Similarly, the competitive conditions that prevail in the Jordanian banking sector would be most useful to investigate, as this aspect has a number of implications.

\section{REFERENCES}

Allen, F., Demirgüc-Kunt, A., Klapper, L., Peria, M. (2016), "The Foundations of Financial Inclusion: Understanding Ownership and Use of Formal Accounts", Journal of Financial Intermediation 27: 1-30.

Almarzoqi, R. (2015), "What Matters for Financial Development and Stability?”, IMF Working Paper No. 15/173, Washington: International Monetary Fund.

Arestis, P., P. Demetriades and K. Luintel (2001), "Financial Development and Economic Growth: The Role of Stock Markets", Journal of Money, Credit and Banking 33: 16-41.

Bagehot, W. (1873), Lombard Street, Homewood, IL: R. Irwin 1962 edition.

Beck, T. (2016), "Finance, Institutions, and Economic Development: Literature Survey and Research Agenda", Economic Development and Institutions Working Paper No. 16/7, Cass Business School.

Berthelemy, J. and A. Varoudakis (1996), "Economic Growth, Convergence Clubs, and the Role of Financial Development", Oxford Economic Papers 48: 300-28.

Caporale, G., S. Lodh and M. Nandy (2015), "The Performance of Banks in the MENA Region During the Global Financial Crisis", Discussion Paper 1580, DIW Berlin, German Institute for Economic Research, Berlin.

Catao, L. and Terrones (2016), "Financial De-Dollarization: A Global Perspective and the Peruvian Experience", IMF Working Paper No. 16/97, Washington: International Monetary Fund.

Chandavarkar, A. (1992), “Of Finance and Development: Neglected and Unsettled Questions”, World Development $20: 133-42$.

Chang, R. and A. Velasco (2001). "Monetary Policy in a Dollarized Economy Where Balance Sheets Matter", Journal of Development Economics 66: 445-464.

Cherif, M. and Dreger, C. (2016), "Institutional Determinants of Financial Development in MENA Countries", Review of Development Economics 20: 670-680. 
Cihac, M. A. Demirguc-Kunt, E. Feyen and R. Levine (2012), "Benchmarking Financial Development Around the World", World Bank Policy Research Working Paper 6175, World Bank, Washington, DC.

Chortareas, G., J. Garza-Garcia G. Girardone (2011), "Banking Sector Performance in Latin America: Market Power Versus Efficiency", Review of Development Economics 15: 307-325.

Dabla-Norris, E. and N. Srivisal (2013), "Revisiting the Link Between Finance and Macroeconomic Volatility", IMF Working Paper 13/29, Washington: International Monetary Fund.

Dabla-Norris, E., Ji, Y., Towsend, R. and Unsal, F. (2015), "Identifying Constraints to Financial Inclusion and their Impact on GDP and Inequality: A Structural Framework for Policy', IMF Working Paper No. 22.

DeHan, Chase, Determinants of Financial Development: How Equality of Access Impacts Private Credit (June 9, 2016). Available at SSRN: https://ssrn.com/abstract=2792829

Demirguc-Kunt, A. and H. Huizinga (1999), "Determinants of Commercial Bank Interest Margins and Profitability: Some International Evidence", World Bank Economic Review 13: 379-408.

Demirguc - Kunt, A. and H. Huizinga (2001), "Financial Structure and Bank Profitability”, in Financial Structure and Economic Growth: A Cross-Country Comparison of Banks, Markets, and Development. Cambridge and London: MIT Press.

Fungacova, Z. and T. Poghosyan (2011), “Determinants of Bank interest Margins in Russia: Does Bank Ownership Matter?”, Economic Systems 3: 481-495.

Fungacova, Z. and L. Weill (2014), "Understanding Financial Inclusion in China”, BOFIT Discussion Paper 10, Bank of Finland.

Gurbuz, A., S. Yanik and Y. Ayturk (2013), "Income Diversification and Bank Performance: Evidence from Turkish Banking Sector", Journal of BRSA Banking and Financial Markets 7: 9-29.

Hamdi, K. (2015), "The Determinants of Financial Development: Empirical Evidence from Developed and Developing Countries", Applied Economics and Finance 2: 1-9.

Hashem, H. (2016), “Determinants of Egyptian Banking Sector Profitability: Time series Analysis from 2004-2014”, International Journal of Business and Economic Sciences Applied Research 9: 73-78.

Helhel, Y. (2015), “Evaluating The Performance of the Commercial Banks In Georgia", Research Journal of Finance and Accounting 5: 146156.

Heng, D., A. Ivanova, R. Mariscla, U. Ramakrishnan, and J. Wong (2016), “Advancing Financial Development in Latin America and the Caribbean", IMF Working Paper No. 16/81, Washington: International Monetary Fund.

Kasman, A., G. Tung and G. Vardar (2014), "Consolidation and Commercial Bank Net Interest Margins: Evidence from the Old and New European Union Members and Candidate Countries", Economic Modeling 12: 23-45.

King, R. and R. Levine (1993), "Finance and Growth: Schumpeter Might be Right", Quarterly Journal of Economics 108:717-37.

Kubo, K. (2007), “Do Foreign Currency Deposits Promote or Deter Financial Development in Low-Income Countries? An Empirical Analysis of Cross-Country Data", Institute of Developing Economies, Discussion Paper No. 87.

Kutan, A., E. Rengifo, and E. Ozsoz(2010), "Evaluating the Effects of Deposit Dollarization in Bank Profitability", Fordham University, Discussion Paper No. 07.

Law, S. and P. Demetriades (2004), "Capital Inflows, Trade Openness and Financial Development in Developing Countries", Money Macro and Finance (MMF) Research Group Conference, Money Macro and Finance Research Group.

Le, T., J. Kim and M. Lee (2016), "Institutional Quality, Trade Openness, and Financial Sector Development in Asia: An Empirical Investigation", Emerging Markets Finance and Trade 52: 1047-1059.

Levine, R. (2004), "Finance and Growth: Theory and Evidence", NBER, Working Paper No. 10766.

Lucas R. (1988), “On the Mechanics of Economic Development”, Journal of Monetary Economics 22: 3- 42.

Marcelin, I. and I. Mathur (2016), "Financial Sector Development and Dollarization in Emerging Economies", International Review of Financial Analysis 46: 20-32.

McKinnon, R. (1973), Money and Capital in Economic Development, Washington: The Brookings Institution.

Mehorata, A. and Yetman, J. (2015), "Financial Inclusion - Issues for Central Banks”, BIS Quarterly Review, March, p. 83-96.

Naceur, S. and M. Omran (2011), "The Effects of Bank Regulations, Competition, and Financial Reforms on Banks' Performance", Emerging Markets Review, 12, p. 1-20.

Nassar, K., E. Martinez, and A. Pineda (2015), “Determinants of Banks' Net Interest Margins in Honduras”, IMF Working Paper No. $14 / 163$.

Pagano, M. (1993), "Financial Markets and Growth: An Overview”, European Economic Review 37: 613-22.

Park, C. and Mercado, R. (2015), "Financial Inclusion, Poverty, and Income Inequality in Developing Asia", Asian Development Bank, Working Paper No. 426. 
Rajan, R. and L. Zingales, L. (2003), "The Great Reversals: The Politics of Financial Development in the Twentieth Century", Journal of Financial Economics 69: 5-50.

Rengifo, E., E. Court, and E. Ozsoz, E. (2010), "Deposit Dollarization and its Impact on Financial Deepening in the Developing World", Fordham University Department of Economics Discussion Paper No. 2010-08.

Robinson, J. (1952), The Generalization of the General Theory, in The Rate of Interest and Other Essays, MacMillan, London, UK.

Schumpeter, J. (1934), The Theory of Economic Development, 1912, Translated by Redvers Opie. Harvard University Press, Cambridge, USA. Shaw, E. (1973), Financial Deepening in Economic Development, New York: Oxford University Press.

Svirydzenka, K. (2016), "Introducing a New Broad-Based Index of Financial Development", IMF Working Paper No. 16/5, Washington: International Monetary Fund.

Trujillo-Ponce, A. (2013), "What Determines the Profitability of Banks? Evidence from Spain”, Accounting and Finance, 53, p. 561-586.

Tuesta, D., G. Sorensen, A. Haring and N. Camara (2015), "Financial Inclusion and its Determinants: The Case of Argentina", BBVA Working Paper No. 15/03, Madrid.

Vieira, F., M. Holland, and Resende, M. (2012). "Financial Dollarization and Systemic Risks: New Empirical Evidence", Journal of International Money and Finance 31: 1695-1714.

Yaseen, H., G. Omet and F. Khamash (2015), "On the Entry of Foreign Banks: The Jordanian Experience", International Journal of Economics and Finance 7: 278-282.

Zigraiova, D. and T. Havranek (2015), "Bank Competition and Financial Stability: Much Ado About Nothing?", Journal of Economic Surveys 30: 944-981.

Zins, A. and L. Weill (2016), "The Determinants of Financial Inclusion in Africa”, Review of Development Finance 6: 46-57. 